\title{
CAUSALITY AND COINTEGRATION AMONG STOCK MARKET INDICES: A STUDY OF DEVELOPED MARKETS WITH SENSEX
}

\author{
Dr. Nisarg A Joshi \\ Associate Professor \\ Shanti Business School, Ahmedabad - 380058, India \\ E-mail: nisargjoshi@shantibschool.edu.in \\ Dr. Dhyani Mehta \\ Assistant Professor \\ Institute of Management, Nirma University, Ahmedabad - 382481, India \\ E-mail: dhyanimehta@nirmauni.ac.in \\ Dr. Bhavesh Patel \\ Assistant Professor \\ Institute of Management, Nirma University, Ahmedabad - 382481, India \\ E-mail: bhavesh@nirmauni.ac.in

\section{Dr. Nikunj Patel} \\ Assistant Professor \\ Institute of Management, Nirma University, Ahmedabad - 382481, India \\ E-mail: nikunj@nirmauni.ac.in
}

\begin{abstract}
The aim of this paper is to examine the existence of degree of interdependence between Sensex and various stock markets of the American and European regions. The study attempts to analyse the dynamic interactions among 22 global indices. The daily closing prices of indices were obtained from the respective stock exchange websites from January 2005 to May 2018. The normality, stationarity, and causality of the time series were evaluated in the first section using statistical techniques such as the Jarque-Bera statistic, ADF test, and Granger Causality test. The second part of the approach focused on analysing the interdependencies of various stock markets, determining the degree of association, and measuring market efficiency using techniques such as Johansen's Cointegration test, Cross-Correlation test, and Hurst Exponent. The results indicate that there is a significant amount of interdependence between stock markets. It was also observed that there is an association between markets. This study also found bi-directional as well as uni-directional causality among the stock market indices. The study found that interdependence of markets leads to improvements in short-term as well as long-term returns/gains for investors possibly due to international portfolio diversification if there are stronger co-movements of prices across the markets.
\end{abstract}

Keywords: Cointegration, Cross Correlation, Market Efficiency, Interdependence, Causality.

JEL Classification Codes: G15, F15, F21. 


\section{INTRODUCTION}

Integration of international stock indices in last three decades had been observed due to major deliberate unconventionalities beneath which global investment limits were minimized, exchange rate controls were removed, movement of capital was encouraged, exchange of human and technology was endorsed and the fundamental structure of the global markets was distorted. Market integration has been promoted through liberalization, which has critical implications on investment decisions and policies.

The changing aspects of the growth of an economy is predictable. There is a huge amount of consideration given to the scrutiny of relationships among the international stock indices. The home country or index can be connected with global stock indices through financial integration. With the increased integration among the markets, it is possible to diversify the risk in a better way. Cost of financial contagion and crisis can be avoided by global financial openness (Park \& Lee, 2011).

The main reason for cointegration is coming from efficient market hypothesis (EMH). According to $\mathrm{EMH}$, any arrival of the new information is reflected in the stock prices. The variation in stock prices in one market is not persistent to the change in the prices of other indices. Therefore, it is imperative to investigate the variations in stock prices in one market due to variations in various factors in other markets. The major reason for cointegration among different stock markets is because of augmented international capitalization due to various variables such as growth of MNCs, technological development, liberalization of financial markets and systems, relaxation of foreign exchange policies resulting into upsurge in capital movements etc. Such variations in stock prices across the markets results into higher profits and improved diversification, which eventually leads to cointegration of global stock indices.

Cointegration can be deliberated to comprehend if there are any common factors, which govern the returns of stocks, or an individual market or such stock or market is driven by its own fundamentals. If such common factors are seen across different markets, they are perfectly correlated with each other over a long period of time and considered to be more risky of contagion and ripple effects. The study of cointegration and causality among the markets can help reducing such risks.

Khan (2011) explained two major reasons for cointegration in his study namely global liberalisation of capital flows and a better network of communication which made it easier for investors to invest in global markets. He also concluded that cointegration has also happened due to financially and economically integrated world, which would result in an efficient international financial scope, and various markets would not be able to show independent behaviour of prices. According to (Dorodnykh, 2014), "cointegration is a complex process, and it depends on various macroeconomic, structural, cultural-geographical and operative forces, where different stakeholders can also affect the integration decision."

The studies on the Cointegration between the stock markets has been a vital topic in the financial literature ever since the works of (Granger, 1983) formalized the concept of Cointegration. Later studies of Granger and Weiss (1983) and Engle and Granger (1987) evolved into a model to test the linear relationships among the financial markets. The unfavourable events in one market cause fluctuations in stock prices. Due to the interlinkages with other markets, the fluctuations are spread as a Contagion to the interlinked markets.

The cointegrated and interlinked stock markets can lead to a world-wide crash to begin by a particular news event in one country (Roll, 1989). The studies of Arshanapalli and Doukas (1993), Masih and Masih (1997) and Kizys and Pierdzioch (2009) among others have reported the interlinkages among developed markets of USA, Japan and Europe. The interlinkages between the US, Japan and Asian markets were evidenced by Arshanapalli et al. (1995), Anoruo et al. (2003), and Asgharian et al. (2013) among others. Further, these studies attributed the decline in the stock indices after the United States 
stock market crash of October 1987, Asian Financial Crisis of 1997 and Global Financial Crisis of 2008 to cointegration and interlinkages of stock markets.

Normally, the long-term equilibrium relationship is specified by a bivariate cointegration relationship. In such relationship, the deviation from the equilibrium relationship is found to be stationary with a mean value of zero. It can be interpreted into an application, which can be assessed as a combination of two non-stationary series, which itself is stationary. According to (Engle \& Granger, 1987), such bivariate series is considered to be cointegrated. Such bivariate relationship can be expanded to multivariate relationship. In such relationship, a deviation in the price factors from the long-term relationship can be created from grouping of all the time series. A change in the degree of cointegration among the factors/variables can explain the long-term relationship among global stock markets. This can be achieved through the comparison of cointegration relationship over various sub-sample periods. In this study, the multivariate approach of cointegration is adopted to investigate the cointegration of multiple countries.

\section{LITERATURE REVIEW}

Over the years, various researchers emphasising numerous cointegration parameters such as risk, return, volatility, and prices have conducted a number of studies.

Darrat et al. (2000) investigated the integration of emerging stock markets in the Middle East and found numerous differences in trading patterns, especially in terms of market integration at the national level. Using a VAR model with multivariate GARCH, (Scheicher, 2001) observed cointegration between Eastern European and Western European markets and concluded that Eastern markets were more influenced by Western markets.

Brooks and Del Negro (2004) argued that the international equity market has the lowest degree of correlation returns across national stock markets. After the financial crisis (Click \& Plummer, 2005; Majid et al., 2009; Phuan et al., 2009) investigated stock market integration in ASEAN and found that cointegration of five ASEAN markets had not been completed in economic sense. (Mukherjee \& Mishra, 2005) observed long-term cointegration among Indian stock market and other Asian stock markets. However, (Gupta \& Guidi, 2012) found no evidence of cointegration between the Indian and Asian stock markets. According to the study, the long-term benefits of investing in India are extremely small. Another research (Chittedi, 2010) looked at the relationship between the stock markets of developed countries and the stock markets of India and noticed that they were not cointegrated. This is in line with the findings of Nath \& Verma (2003), who found no cointegration between three South Asian stock markets: India, Taiwan, and Singapore. Bhunia and Das (2012) looked into the integration of financial markets in India and a few other South Asian countries. Authors observed no cointegration of the developed markets with the Indian stock market. Bhunia \& Das (2012) looked into the integration of financial markets in India and a few other South Asian countries. Authors observed no cointegration of the developed markets with the Indian stock market. Joshi (2013) examined at the cointegration of BRIC stock indices and found that India and Russia had a long-term equilibrium relationship, but not with Brazil. (Patel, 2014) presented an investigation into the cointegration of Indian and Asian capital markets. The study revealed that stock indices from China, Sri Lanka, Singapore, and Japan influenced India's stock market. Bhattacharjee \& Swaminathan (2016) examined at the stock market integration of India and a few other countries and observed that cointegration of the Indian market with other indices has strengthened over time because of liberalisation, and that during the slowdown; the Indian market was more open to Asian markets.

Thalassinos \& Thalassinos (2006) found that the establishment of the EMU had a major impact on European stock market integration as compared to other countries. They also concluded that there was a relation between bilateral import dependency and the degree of stock market integration. Wang and 
Moore (2008) analysed the stock market integration for the transition economies by using time-varying conditional correlation. Since joining the European Union, they found a very high degree of correlation. Chen amd Shen (2009) investigated the cointegration of stock markets in the United Kingdom, the United States, Japan, and Germany and found market integration. Chancharat (2009) used econometric techniques such as the cointegration test, factor analysis, and GARCH models to investigate the relationship between economic variables and stock market integration. Raju \& Khanapuri (2009) investigated cointegration among Asian emerging stock markets and discovered a high degree of cointegration among the markets. According to Modi et al. (2010), the US market is the most influential. Baumöhl \& Výrost (2010) examined at cointegration with non-synchronous trading effects using the granger causality test and found that there was no substantial lead-lag relationship of stock market integration in the pre- and post-crisis period. According to Yeoh et al. (2010), the Malaysian stock market has a higher degree of cointegration.

Sharma and Seth (2012) used the Granger causality test and the Johnsen cointegration test to investigate market cointegration between Asian and US markets and observed short and long term cointegration. Mitra \& Bhattacharjee (2015) found cointegration of the BSE with other markets. Using beta-convergence and sigma-convergence methods, (Babecký et al., 2013) investigated cointegration between Chinese and Russian stock markets. Birău \& Trivedi, (2013) investigated emerging market stock market cointegration and contagion in the context of the global financial crisis. The instability in the financial sector has resulted in a significant drop in stock markets around the world. Down markets have higher levels of contemporaneous systematic risk and a higher market risk premium, according to Bhattacharya et al. (2020). Shahzad et al. (2016) used ARDL approach to investigate cointegration among stock markets and found the existence of cointegration.

Okon (2018) aimed at the cointegration and causality of macroeconomic factors and terrorism in Nigeria and concluded that trade openness should be maintained and strategic macroeconomic policies should be implemented in order to develop the Nigerian economy. Kiviet and Chen (2018) reviewed the literature on the study of cointegration between stock price indices or realised returns at different markets and found a number of common methodological flaws, including omitted regressor problems, failing to check agreement of estimation outcomes with adopted model assumptions, and using specific statistical tests in inappropriate situations and, occasionally and lack of identification. Nautiyal and Kavidayal (2018) used VECM to analyse cross-country returns and cointegration of 11 stock indices from developed and developing countries. They detected a sluggish but significant price adjustment as well as stock market cointegration. On the Dhaka stock exchange, Golder et al. (2020) found a causal relationship between foreign exchange reserves, exchange rate, and index.

\section{HYPOTHESIS DEVELOPMENT}

$\mathrm{H}_{0}{ }^{1}$ : Stock indices follow normally distribution.

$\mathrm{H}_{0}{ }^{2}$ : The time series are not stationary. (Dickey \& Fuller, 1979, 1981)

$\mathrm{H}_{0}{ }^{3}: \mathrm{x}(\mathrm{t})$ doesn't Granger-cause $\mathrm{y}(\mathrm{t})$. (There is no causal relationship between stock indices)

The focus of the methodology's second section is on analysing stock market interdependencies, determining the degree of linkage, and examining market integration using various approaches such as Johansen's Cointegration test, Cross Correlation test, and Hurst Exponent. The trace test and the eigenvalue value were used in conjunction with Johansen's Cointegration test.

$\mathrm{H}_{0}{ }^{4}$ : the number of cointegration vectors is $\mathrm{r}=\mathrm{r}^{*}<\mathrm{k}$ (Null Hypothesis for trace test as well as eigenvalue test) 
$\mathrm{H}_{0}{ }^{5}$ : cross-correlation is not significantly different from zero.

$\mathrm{H}_{0}{ }^{6}$ : stock price variations are independent.

\section{Data Sources}

\section{METHOD}

The closing data of daily prices of several indices were obtained from the respective stock exchange websites from January 2005 to December 2018, for this study. The behaviour of SENSEX along with 21 stock indices from European and American markets are studied to investigate cointegration. The major stock indices of European markets (AEX, ATX, BEL20, BIST100, CAC40, DAX, FTSE100, IBEX, OMX, OSE ALL SHARE, RTSI, SMI and STOXX50) and stock indices of American market (DJIA, GSPC, IBOVESPA, IPC, MERVAL, NASDAQ, NYSE and S\&P TSX) were selected for this study along with Indian stock market index (SENSEX).

\section{Methodology}

A two-stage technique was used in this investigation. The normality, stationarity, and causality of the time series were verified in the first section using statistical techniques such as the Jarque-Bera Statistic, ADF Test, and Granger Causality Test. Cointegration analysis, cross-correlation analysis, and Hurst Exponent analysis are all included in the second section.

\section{Descriptive Statistics}

\section{RESULTS}

The descriptive statistics show that the mean daily returns of the majority of the indices in the sample were positive, however the SENSEX index had the highest returns (0.06) among all the indices, followed by the IPC index, and the OSE index had the lowest (-0.02) among all. Statistics on the standard deviation of daily returns in emerging markets show that these markets are more volatile. In general, developed market returns are less volatile than emerging market returns, with a lower standard deviation. However, the standard deviation of US DJIA (4.71) is highest, while the Australian market has the lowest level of volatility in the developed market sample.

Table 1. Descriptive Statistics of sample indices

\begin{tabular}{|c|c|c|c|c|c|c|c|c|c|c|c|c|}
\hline INDICES & Mean & Median & Max & Min & $\begin{array}{c}\text { Std. } \\
\text { Dev. }\end{array}$ & Kurtosis & Skewness & JB & $\begin{array}{c}\text { P- } \\
\text { Value }\end{array}$ & $\begin{array}{c}\text { Sum } \\
\text { Sum Sq. } \\
\text { Dev. }\end{array} \begin{array}{c}\text { ADF } \\
\text { Test }\end{array}$ \\
\hline AEX & 0.02 & 0.05 & 10.55 & -9.14 & 1.35 & 11.83 & 0.02 & 9150.22 & 0.000 & 48.58 & 5161.12 & $-53.64^{*}$ \\
\hline ATX & 0.01 & 0.07 & 12.77 & -9.74 & 1.65 & 8.74 & -0.07 & 3887.16 & 0.000 & 30.33 & 7673.18 & $-49.72^{*}$ \\
\hline BEL 20 & 0.01 & 0.03 & 9.66 & -7.98 & 1.27 & 9.24 & -0.002 & 4743.64 & 0.000 & 40.54 & 4735.71 & $-52.61^{*}$ \\
\hline BIST 100 & 0.05 & 0.08 & 12.89 & -10.47 & 1.73 & 3.52 & -0.12 & 1430.29 & 0.000 & 145.28 & 8310.4 & $-51.16^{*}$ \\
\hline CAC 40 & 0.02 & 0.04 & 11.18 & -9.04 & 1.45 & 9.48 & 0.2 & 5121.59 & 0.000 & 46.04 & 6098.94 & $-56.55^{*}$ \\
\hline DAX & 0.04 & 0.1 & 11.4 & -7.16 & 1.4 & 9.46 & 0.17 & 5077.95 & 0.000 & 115.76 & 5713.37 & $-54.08^{*}$ \\
\hline DJIA & 0.13 & 0.09 & 56.8 & -30.31 & 4.71 & 34.04 & 2.16 & 116304.8 & 0.000 & 355.6 & 63093.6 & $-16.04^{*}$ \\
\hline FTSE 100 & 0.02 & 0.01 & 9.84 & -8.85 & 1.19 & 11.33 & 0.03 & 8548.11 & 0.000 & 46.72 & 4181.57 & $-26.07^{*}$ \\
\hline $\begin{array}{c}\text { GSPC S\&P } \\
\text { 500 }\end{array}$ & 0.03 & 0.07 & 11.58 & -9.03 & 1.26 & 13.97 & -0.09 & 14087.69 & 0.000 & 80.54 & 4481.09 & $-24.82^{*}$ \\
\hline IBEX & 0.01 & 0.07 & 14.43 & -9.14 & 1.52 & 9.7 & 0.27 & 5477.53 & 0.000 & 32.79 & 6769.31 & $-55.05^{*}$ \\
\hline IBOVESPA & 0.04 & 0.02 & 14.66 & -11.39 & 1.79 & 8.67 & 0.22 & 3820.28 & 0.000 & 108.51 & 9044.04 & $-40.03^{*}$ \\
\hline
\end{tabular}




\begin{tabular}{|c|c|c|c|c|c|c|c|c|c|c|c|c|}
\hline IPC & 0.05 & 0.08 & 11.01 & -7.01 & 1.29 & 9.8 & 0.28 & 5444.88 & 0.000 & 150.65 & 4651.76 & $-53.83^{*}$ \\
\hline MERVAL & 0.1 & 0.12 & 11 & -12.15 & 2.02 & 6.41 & -0.31 & 1406.99 & 0.000 & 280.33 & 11482.1 & $-52.11^{*}$ \\
\hline NASDAQ & 0.04 & 0.09 & 11.81 & -9.14 & 1.34 & 10.46 & -0.06 & 6661.31 & 0.000 & 109.21 & 5183.12 & $-51.21^{*}$ \\
\hline NYSE & 0.02 & 0.06 & 12.22 & -9.73 & 1.32 & 13.68 & -0.16 & 13662.26 & 0.000 & 62.34 & 4966.89 & $-55.35^{*}$ \\
\hline OMX & 0.04 & 0.08 & 9.01 & -7.12 & 1.36 & 7.68 & 0.06 & 2614.65 & 0.000 & 101.82 & 5294.42 & $-49.04^{*}$ \\
\hline OSE & -0.02 & -0.11 & 10.2 & -8.78 & 1.55 & 9.05 & 0.75 & 4562.05 & 0.000 & -65.53 & 6778 & $-54.30^{*}$ \\
\hline RTSI & 0.04 & 0.08 & 22.39 & -19.1 & 2.25 & 13.9 & 0.09 & 14179.01 & 0.000 & 111.13 & 14460.5 & $-52.27^{*}$ \\
\hline S\& P TSX & 0.02 & 0.07 & 9.82 & -9.32 & 1.15 & 13.24 & -0.47 & 12808.58 & 0.000 & 61.24 & 3841.13 & $-48.95^{*}$ \\
\hline SENSEX & 0.06 & 0.09 & 17.34 & -10.96 & 1.52 & 12.53 & 0.32 & 10688.63 & 0.000 & 170.96 & 6511.39 & $-49.23^{*}$ \\
\hline SMI & 0.02 & 0.06 & 11.39 & -8.67 & 1.15 & 11.91 & -0.06 & 9590.69 & 0.000 & 54.3 & 3805.81 & $-26.52^{*}$ \\
\hline STOXX50 & 0.01 & 0.02 & 11 & -7.88 & 1.45 & 9.19 & 0.17 & 4462.43 & 0.000 & 39.37 & 5852.77 & $-26.21^{*}$ \\
\hline
\end{tabular}

Emerging market skewness values, such as Russia's, have an asymmetrical distribution with a long tail to the left, whereas India's condition is close to zero and has merely an asymmetrical distribution. The US stock market has a symmetric distribution around the average value in developed markets. Other established markets, such as the United Kingdom exhibits left skewed distribution. All of the stock market Kurtosis values in this study are greater than three, indicating a leptokurtic curve. These findings are consistent with (Harvey, 1995), (Bekaert et al., 1998). The use of a sub-optimal mean-variance criterion in portfolio construction can result in significant opportunity cost for risk-averse investors. The ADF test was used to determine that the variables are stationary or not. All the time series was found stationary at $1^{\text {st }}$ difference.

\section{Test for Causality}

Granger causality test was performed to examine the causal relationship among these markets. Since cointegration at any level exists, the Granger causality testing is appropriate for bilateral pairs of markets. As (Granger, 1988) pointed out, if two variables are cointegrated, causality must exist at least unidirectional.

The granger causality test was conducted by dividing the data into 3 sub-periods (Period 1: 2005 - 2009; Period 2: 2010 - 2014; Period 3: 2015 - 2018). The causality of most of the indices remained consistent across all sub-periods. However, in the case of several indices, causality was found in one subperiod (either bi-directional or uni-directional) but not in another sub-period. In a few situations, causality between two indices was uni-directional for one sub-period, bi-directional for another sub-period, and there was no causality between those two indices for the third sub-period. This resulted in a fascinating shift in trend during the short-term Granger causality results. These results for each of the sub-period are shown in the Appendix A and B. These appendices show the results of bi-directional or uni-directional causality of an index with other indices for the long-term i.e. for the entire duration of the study. These long-term results are the combination of all short-term results, which include bi-directional and unidirectional causality of an index with other indices, as well as the bi-directional and uni-directional causality of an index with other indices, which were found in all three sub-periods listed below. For example, the ATX index causes 12 indices from 2005 to 2009, 13 from 2010 to 2014, and 11 from 2015 to 2018.

Appendix A and B, report the Bi-directional Causality and Uni-directional Causality analysis. It can be inferred that there is an existence of bi-directional causality. Among 22 indices AEX index causes 11 indices, ATX causes 8 indices, Bel20 causes 9 indices, CAC40 causes 10 indices, DAX causes 5 
indices, DJIA causes 1 index, FTSE100 causes 9 indices, GSPC S\&P500 causes 11 indices, IBEX causes 6 indices, IBOVESPA causes 4 indices, IPC causes 3 indices, Merval causes 3 indices, Nasdaq causes 10 indices, NYSE causes 10 indices, OMX causes 3 indices, OSE causes 14 indices, RTSI causes 6 indices, S\&P TSX causes 14 indices, Sensex causes 5 indices, SMI causes 5 indices and Stoxx 50 causes 8 indices.

As far as uni-directional causality concerned, AEX causes 6 indices, ATX causes 1 index, BEL20 causes 7 indices, BIST 100 causes 2 indices, CAC40 causes 4 indices, DAX causes 14 indices, DJIA causes 3 indices, FTSE causes 4 indices, GSPC S\&P500 causes 4 indices, IBEX causes 4 indices, IBOVESPA causes 10 indices, IPC causes 12 indices, Merval causes 8 indices, Nasdaq causes 5 indices, NYSE causes 5 indices, OMX causes 3 indices, OSE causes 1 indices, RTSI causes 1 indices, S\&P TSX doesn't cause any index in one way, Sensex doesn't cause any index in one way, SMI causes 14 indices and Stoxx50 causes 3 indices.

\section{Cointegration Test}

The efficient maximum likelihood test (Johansen, 1988, 1991, 1995) was employed to look for a longterm association between indices. A Johansen model with a linear trend in level and intercept in the cointegrating equations was utilised (CE). Because we have trending series with stochastic trends, this version was found to be more appropriate for our data. The test was carried out with a VAR model that had a lag duration specified by AIC and Akaike's Final Prediction Error (FPE). The eigenvalue and trace statistics values are used to calculate the cointegration rank (r).

Maximum likelihood estimators of the cointegrating vectors for an autoregressive process were derived by Johansen (1988) and Johansen \& Juselius (1990) by considering the following equation.

$$
X_{t}=\alpha \beta^{\prime}{ }_{1} X_{t-1}+\cdots+\alpha \beta^{\prime}{ }_{k} X_{t-k}+\delta_{t}+\varepsilon_{t}
$$

VAR model can be estimated at first level difference i.e. 1(1) as majority of time series variables are non-stationary at level 1(0). The above-mentioned equation (1) of Johansen and Juselius (1990) can be represented by introducing first level difference operator as follows:

$$
\Delta X_{t}=\Gamma \Delta X_{t-1}+\cdots+\Gamma_{k-1} \Delta X_{t-k+1}+\Pi X_{t-k}+\delta_{t}+\varepsilon_{t}
$$

$\Pi$ Matrix can be used to trace cointegration. First level difference i.e. 1(1) might be preferred when all Xt value are found to have unit roots which can be determined if $\mathrm{p} x \mathrm{p}$ matrix $\Pi$ has rank 0 .

Cointegration between the SENSEX and other indices is shown in Table 2. Because the trace statistic at $\mathrm{r}=\mathrm{o}$ was higher than the critical value of $5 \%$, the null hypothesis of no cointegration was rejected. The result implied that there was at most one cointegrating equation between the two variables. The results of the OSE and IPC cointegration test were consistent with the correlation analysis, which found that the relationship between the two stock markets' movements was substantially positive.

At the 5\% significance level, trace statistics and Eigen value statistics revealed one cointegrating vector among the markets, as shown in table 2 . Because the trace statistic exceeds the $5 \%$ critical value, the null hypothesis of no cointegrating vectors can be rejected, indicating that one or more cointegrating equations exist. 
Table 2. Results of Cointegration Test for All Indices

\begin{tabular}{|c|c|c|c|c|c|c|c|c|}
\hline \multirow[b]{2}{*}{ SENSEX } & & \multirow[b]{2}{*}{ No. of C.E. } & \multirow[b]{2}{*}{$\begin{array}{l}\text { Eigen } \\
\text { Value }\end{array}$} & \multicolumn{2}{|c|}{ Trace } & \multirow[b]{2}{*}{$\begin{array}{l}\text { Eigen } \\
\text { Value }\end{array}$} & \multicolumn{2}{|c|}{$\begin{array}{l}\text { Maximum Eigen } \\
\text { value }\end{array}$} \\
\hline & & & & $\begin{array}{l}\text { Trace } \\
\text { statistic }\end{array}$ & $P$ value & & $\begin{array}{l}\text { Max } \\
\text { Eigen } \\
\text { statistic }\end{array}$ & $P$ value \\
\hline \multirow[t]{2}{*}{ AEX } & $\begin{array}{l}\text { Co-integration } \\
\text { exists }\end{array}$ & None * & 0.212 & 1351.49 & 15.49 & 0.21 & 756.68 & 14.26 \\
\hline & & At most $1 *$ & 0.171 & 594.81 & 3.84 & 0.17 & 594.81 & 3.84 \\
\hline ATX & & None $*$ & 0.186 & 651.52 & 3.84 & 0.19 & 651.52 & 3.84 \\
\hline \multirow[t]{2}{*}{ BEL20 } & $\begin{array}{l}\text { Co-integration } \\
\text { exists }\end{array}$ & None * & 0.204 & 1319.03 & 15.49 & 0.20 & 724.04 & 14.26 \\
\hline & & At most $1 *$ & 0.171 & 594.99 & 3.84 & 0.17 & 594.99 & 3.84 \\
\hline \multirow[t]{2}{*}{ CAC40 } & $\begin{array}{l}\text { Co-integration } \\
\text { exists }\end{array}$ & None * & 0.226 & 1406.52 & 15.49 & 0.23 & 809.95 & 14.26 \\
\hline & & At most $1 *$ & 0.172 & 596.57 & 3.84 & 0.17 & 596.57 & 3.84 \\
\hline \multirow[t]{2}{*}{ DAX } & $\begin{array}{l}\text { Co-integration } \\
\text { exists }\end{array}$ & None $*$ & 0.237 & 1393.08 & 15.49 & 0.24 & 857.08 & 14.26 \\
\hline & & At most $1 *$ & 0.156 & 536.0 & 3.84 & 0.16 & 536.00 & 3.84 \\
\hline \multirow[t]{2}{*}{ FTSE 100} & $\begin{array}{l}\text { Co-integration } \\
\text { exists }\end{array}$ & None $*$ & 0.212 & 1343.86 & 15.49 & 0.21 & 753.17 & 14.26 \\
\hline & & At most $1 *$ & 0.170 & 590.69 & 3.84 & 0.17 & 590.69 & 3.84 \\
\hline \multirow[t]{2}{*}{ GSPC S\&P500 } & $\begin{array}{l}\text { Co-integration } \\
\text { exists }\end{array}$ & None $*$ & 0.212 & 1327.57 & 15.49 & 0.21 & 754.65 & 14.26 \\
\hline & & At most $1 *$ & 0.165 & 572.92 & 3.84 & 0.17 & 572.92 & 3.84 \\
\hline \multirow[t]{2}{*}{ IBEX } & $\begin{array}{l}\text { Co-integration } \\
\text { exists }\end{array}$ & None $*$ & 0.221 & 1386.11 & 15.49 & 0.22 & 792.90 & 14.26 \\
\hline & & At most $1 *$ & 0.171 & 593.21 & 3.84 & 0.17 & 593.21 & 3.84 \\
\hline \multirow[t]{2}{*}{ IBOVESPA } & $\begin{array}{l}\text { Co-integration } \\
\text { exists }\end{array}$ & None $*$ & 0.211 & 1319.72 & 15.49 & 0.21 & 751.49 & 14.26 \\
\hline & & At most $1 *$ & 0.164 & 568.24 & 3.84 & 0.16 & 568.24 & 3.84 \\
\hline \multirow[t]{2}{*}{ IPC } & $\begin{array}{l}\text { Co-integration } \\
\text { exists }\end{array}$ & None * & 0.203 & 1290.95 & 15.49 & 0.20 & 721.30 & 14.26 \\
\hline & & At most $1 *$ & 0.164 & 569.65 & 3.84 & 0.17 & 569.65 & 3.84 \\
\hline \multirow[t]{2}{*}{ MERVAL } & $\begin{array}{l}\text { Co-integration } \\
\text { exists }\end{array}$ & None * & 0.203 & 1265.24 & 15.49 & 0.20 & 716.89 & 14.26 \\
\hline & & At most $1 *$ & 0.159 & 548.35 & 3.84 & 0.16 & 548.35 & 3.84 \\
\hline \multirow[t]{2}{*}{ NASDAQ } & $\begin{array}{l}\text { Co-integration } \\
\text { exists }\end{array}$ & None ${ }^{*}$ & 0.214 & 1326.42 & 15.49 & 0.21 & 762.90 & 14.26 \\
\hline & & At most $1 *$ & 0.163 & 563.52 & 3.84 & 0.16 & 563.52 & 3.84 \\
\hline \multirow[t]{2}{*}{ NYSE } & $\begin{array}{l}\text { Co-integration } \\
\text { exists }\end{array}$ & None $*$ & 0.217 & 1347.0 & 15.49 & 0.21 & 774.32 & 14.26 \\
\hline & & At most $1 *$ & 0.165 & 572.68 & 3.84 & 0.16 & 572.68 & 3.84 \\
\hline \multirow[t]{2}{*}{ OSE } & $\begin{array}{l}\text { Co-integration } \\
\text { exists }\end{array}$ & None ${ }^{*}$ & 0.199 & 1285.4 & 15.49 & 0.19 & 704.11 & 14.26 \\
\hline & & At most $1 *$ & 0.168 & 581.29 & 3.84 & 0.17 & 581.29 & 3.84 \\
\hline \multirow[t]{2}{*}{ RTSI RUSSIA } & $\begin{array}{l}\text { Co-integration } \\
\text { exists }\end{array}$ & None $*$ & 0.201 & 1248.2 & 15.49 & 0.20 & 709.13 & 14.26 \\
\hline & & At most $1 *$ & 0.156 & 539.09 & 3.84 & 0.16 & 539.09 & 3.84 \\
\hline
\end{tabular}




\begin{tabular}{|l|l|l|l|l|l|l|l|l|}
\hline S\&P TSX & $\begin{array}{l}\text { Co-integration } \\
\text { exists }\end{array}$ & None & 0.213 & 1335.53 & 15.49 & 0.21 & 758.64 & 14.26 \\
\hline & & At most $1 *$ & 0.166 & 576.89 & 3.84 & 0.17 & 576.89 & 3.84 \\
\hline SMI & $\begin{array}{l}\text { Co-integration } \\
\text { exists }\end{array}$ & None & 0.217 & 1328.89 & 15.49 & 0.22 & 774.62 & 14.26 \\
\hline & & At most $1 *$ & 0.161 & 554.27 & 3.84 & 0.16 & 554.27 & 3.84 \\
\hline STOXX50 & $\begin{array}{l}\text { Co-integration } \\
\text { exists }\end{array}$ & None * & 0.226 & 1405.28 & 15.49 & 0.23 & 812.84 & 14.26 \\
\hline & & At most $1 *$ & 0.171 & 592.44 & 3.84 & 0.17 & 592.44 & 3.84 \\
\hline
\end{tabular}

\section{Cross Correlation and Serial Correlation}

Portfolio managers use correlation as one of the simplest but most often used methods in making asset allocation decisions. The measure of strength or degree of linear relationship between two variables is the focus of correlation analysis. The correlation structure of stock market returns provides an initial indication of stock market interconnections. Stock markets with high correlation coefficients can be perceived as having strong connections. Low correlation, on the other hand, demonstrates the stock market's separation property and, as a result, the possibility of risk diversification. Furthermore, markets in the same region are more correlated since they are more susceptible to being influenced by regional news and developments, as well as trade and economic linkages. The correlation structure of emerging and mature markets was investigated to see if there was any preliminary evidence of potential diversification benefits in the region.

The existence of timing differences between emerging stock markets and select developed stock markets, particularly for the US stock market, is one of the procedural difficulties to be handled in the context of the log return correlation matrix in the table. The remaining markets in the sample interact with one another in a single day, and all of the emerging markets under consideration operate in the same time zone. As a result, the contemporaneous correlation between the US market and the selected markets is of little significance. As a result, the correlation matrix is calculated using one-day lagged returns for the US market. Throughout the investigation, the same technique is used for subsequent examination of return data.

The examination of correlation structure of log returns from Table 3, 4 and 5 gives following important findings

Emerging market stock markets have a mixed correlation coefficient with each other and with a few developed stock markets. At the same time, it is worth noting that for the whole sample period, emerging equity markets exhibit low correlation coefficients (less than 0.50). Russia's stock market has a strong correlation coefficient with developed stock markets such as the United Kingdom and the United States, as well as a positive correlation with India.

With respect to the Indian stock market, the lowest correlation coefficients are with the German (European) stock market, and India has no negative correlation with any index. With emerging market Russia, followed by India, the developed US stock market has a positive correlation coefficient.

Sensex is positively correlated with all the indices. It indicates that Sensex, BIST100, SMI and DAX indices following the same trend. There is low positive correlation exist between Sensex and BIST100, SMI and DAX.

In the case of developed countries, the majority of the lags values are positive, indicating a positive correlation between the stock returns of Germany and the stock returns of the United States. The stock returns in Germany and the United States are clearly going in lockstep. We can claim that the stock return in Germany is influenced by the stock return in the United States. In the instance of the UK cross correlation test, seven out of eleven lags are positive, indicating a positive connection between the UK 
and US stock markets. The UK stock market and the US stock market are clearly moving in tandem. We can say that the UK stock market dependent on US stock market. France and Italy's cross-correlation data demonstrate that there are mainly positive lags values, indicating a positive connection with US market returns. The stock markets in France and Italy are clearly moving in unison with the stock markets in the United States.

Table 3. Findings and Inference of High Correlation of Indices

\begin{tabular}{|l|l|}
\hline \multicolumn{2}{|l|}{ Highly Correlated : $>\mathbf{0 . 5 0}$} \\
\hline Bel20 & FTSE100 \\
\hline CAC40 & FTSE100 and Bel20 \\
\hline IBEX & FTSE100, Bel20 and CAC40 \\
\hline S\&P TSX & FTSE100 \\
\hline NASDAQ & FTSE100, Bel20, CAC40, IBEX and S\&P TSX \\
\hline OMX & FTSE100, BEL20, CAC40, IBEX \\
\hline IBOVESPA & FTSE100, Bel20, CAC40, S\&P TSX, Nasdaq, NYSE and OMX \\
\hline ATX & FTSE100, Bel20, CAC40, IBEX, NYSE and OMX \\
\hline OSE & FTSE100, CAC40, OMX and ATX \\
\hline GSPC & FTSE100, BEL20, CAC40, S\&PTSX, NASDAQ, NYSE, OMX and IBOVESPA \\
\hline S\&P00 & FTSE100, BEL20, CAC40, S\&P TSX, NASDAQ, NYSE, OMX, IBOVESPA and \\
\hline IPC & S\&P500 \\
\hline AEX & FTSE100, BEL20, CAC40, IBEX, NASDAQ, NYSE, OMX, IBOVESPA, S\&P500, \\
\hline RTSI Russia & FTSE100, BEL20, CAC40, OMX, ATX and AEX \\
\hline Merval & Nasdaq, NYSE, IBOVESPA, S\&P500 and IPC \\
\hline STOXX50 & $\begin{array}{l}\text { FTSE100, BEL20, CAC40, IBEX, NASDAQ, NYSE, OMX, IBOVESPA, S\&P500, } \\
\text { ATX, IPC, AEX, RTSI RUSSIA }\end{array}$ \\
\hline
\end{tabular}

Table 4. Findings and Inference for High Degree of Anti-correlation

\begin{tabular}{|l|l|}
\hline Highest degree of Anti-correlation \\
\hline BIST100 & FTSE100, CAC40, NASDAQ, AEX \\
\hline DJIA & BIST100 \\
\hline
\end{tabular}

Table 5. Findings and Inference for Low Degree of Anti-correlation

\begin{tabular}{|l|l|}
\hline Lowest degree of Anti-correlation \\
\hline DAX & FTSE100 \\
\hline OSE & DAX \\
\hline BIST100 & IBOVESPA and IPC \\
\hline
\end{tabular}

To examine if there is a problem of serial correlation, the Durbin Watson statistics of the model is 2.14 , which infers that there is no problem of serial correlation. Regression is spurious if the residual 
of the regression is auto-correlated i.e. they are not stationary at level. Autocorrelation among residuals is checked using correlogram of residuals and unit root test; estimates of Q-statistics are statistically insignificant for all 36 lags. This means the null hypothesis of no autocorrelation cannot be rejected. Furthermore, the residuals are also stationary. This finding implies the existence of a long-run equilibrium relationship among the variables. In this case, OLS estimation is consistent, and there is no problem of spurious regression.

\section{Hurst Exponent Analysis}

The independence of stock price changes is a fundamental assumption in quantitative finance theories. Brownian motion can be used to demonstrate such changes. Hurst exponent analysis is used to test for independence in time series data for this purpose. Hurst exponent value of 0.5 explains that the time series is independent. Predetermined Brownian motion data, on the other hand, will yield a Hurst exponent value that can be greater or lower than 0.5 . In the absence of a suitable test, such a value could be misinterpreted as evidence of long-term memory.

Based on the Hurst exponent value $\mathrm{H}$, a time series can be classified into three categories.

(1) $\mathrm{H}=0.5$ indicates a random series.

(2) $0<\mathrm{H}<0.5$ indicates an anti-persistent series.

(3) $0.5<\mathrm{H}<1$ indicates a persistent series.

Mean-reversion is an attribute of a time series, which is anti-persistent. The term "meanreversion" refers to the movement of a previous value in the opposite direction. In the case of the Hurst Exponent, the property of mean-reversion improves as $\mathrm{H}$ approaches 0 . A persistent time series, on the other hand, reinforces the previous value trend. When the value of $\mathrm{H}$ approaches 1 , the consistency of the trend improves. When the Hurst exponent value is greater than 0.5 , the majority of the time series are determined to be persistent.

Table 6. Results of Hurst Exponent Analysis

\begin{tabular}{|l|l|l|}
\hline Indices & H for Return & H Return result \\
\hline AEX & 0.5915 & Persistence \\
\hline ATX & 0.5494 & Persistence \\
\hline BEL20 & 0.6933 & Persistence \\
\hline BIST100 & 0.5389 & Persistence \\
\hline CAC40 & 0.6085 & Persistence \\
\hline DAX & 0.5962 & Persistence \\
\hline DJIA & 0.6328 & Persistence \\
\hline FTSE100 & 0.5154 & Random walk \\
\hline GSPC S\&P 500 & 0.6363 & Persistence \\
\hline IBEX & 0.5201 & Persistence \\
\hline IBOVESPA & 0.4861 & Anti-persistence \\
\hline IPC & 0.4825 & Anti-persistence \\
\hline MERVAL & 0.6491 & Persistence \\
\hline NASDAQ & 0.5361 & Persistence \\
\hline
\end{tabular}




\begin{tabular}{|l|l|l|}
\hline NYSE & 0.5983 & Persistence \\
\hline OMX & 0.6231 & Persistence \\
\hline OSE & 0.5802 & Persistence \\
\hline RTSI RUSSI & 0.5000 & Random walk \\
\hline S\&P TSX & 0.4952 & Anti-persistence \\
\hline SENSEX & 0.5205 & Random walk \\
\hline SMI & 0.6169 & Persistence \\
\hline STOXX50 & 0.6040 & Persistence \\
\hline
\end{tabular}

Table 6 shows that 16 of the 22 indices in the sample follow the persistence trend, 3 indices follow the random trend, and the other 3 indices follow the anti-persistence trend. An increase in values in a persistent time-series will very certainly be followed by another increase in the near term, and a reduction in values will almost certainly be followed by another reduction in the near term. Random trend means there is no correlation between observations and future observations. Series of this kind is very difficult to predict. In anti-persistence trend, an increase will most likely be followed by a decrease and vice versa. This means that future numbers will tend to converge around a long-term average.

\section{CONCLUSION}

The research examined at the co-integration of 22 stock indices from around the world. The cointegration test was used to investigate stock market interdependencies and dynamic interactions, and it was found that co-integration exists between the Indian Stock Market (Sensex) and other indexes.

The null hypothesis of no co-integration was rejected since the trace statistic was higher than the crucial value of 5\%. The result implied that there was at most one co-integrating equation between the two variables. Multiple equations based on the VAR model were used to conduct a co-integration test for a group of 22 stock exchanges in order to evaluate market integration as a whole. Trace statistics indicated at least one co-integrating vector at the 5 percent significance level among the markets.

This study also ascertained the degree of association between developed and emerging markets. Cross correlation was used to ascertain the association and found that out of 22 indices, there were 15 indices who were highly correlated with one or more indices. Two indices exhibited a high degree of anti-correlation, whereas the other three had a low degree of anti-correlation. The correlation analysis revealed that there was a strong positive association between the two stock markets' movements. The stock market indexes were also found to have bi-directional and uni-directional causality in this study. According to the Hurst Exponent analysis, 16 of the 22 indices in the sample follow a persistence trend, three indices follow a random trend, and the other three indices follow an anti-persistence trend.

\section{RESEARCH IMPLICATIONS}

This study contributes in the following ways. First, co-integration can be considered companionable to the perception of integration of financial markets. This embraces homogeneity in investment avenues, allowing stockholders from many markets to invest in a diverse selection of securities. Because the returns from multiple stock markets are not perfectly correlated, cointegration among stock indexes shows that increased returns from international diversification are conceivable. Institutional and overseas investors can profit from the diversification benefits of markets with low correlation. As a result, investors that diversify their portfolio across multiple countries can increase the portfolio's expected return while lowering its risk. This study can help FIIs and private investors to fathom the 
correlation structure and interdependence of global stock indices, allowing them to diversify their portfolios more effectively.

Further, these results are recommended to policymakers, regulators and researchers on the one hand and firms' managers as well as investors on the other. FIIs, HNIs, individual, institutional and public investors can make decisions regarding their investments based on co-integration among the markets, which may be of short as well as long-run. These results provide insights to the investors for portfolio diversification, which can help, reduce the diversifiable risk of the portfolio.

\section{LIMITATIONS OF THE STUDY}

This research is based on secondary data from stock market indices using daily closing prices. The weekly and monthly prices, which might be used for further analysis such as seasonality in stock indices, are not included in this study.

The existence of a temporal difference or difference in trading hours between emerging stock markets and select developed stock markets, particularly the US stock market, is one of the procedural difficulties to be handled in the context of log return correlation matrix. The study also has a disadvantage in that it does not address event-specific co-integration.

\section{SCOPE FOR FURTHER RESEARCH}

The study has a deeper research focus. Regression analysis can be used to investigate each market's dependence on other markets. The analysis of dependency can assist in making better financial decisions. The impact of market volatility can also be studied.

\section{REFERENCES}

Anoruo, E., Ramchander, S., \& Thiewes, H. (2003). Return dynamics across the Asian equity markets. Managerial Finance, 29(4), 1-23. https://doi.org/10.1108/03074350310768265

Arshanapalli, B., \& Doukas, J. (1993). International stock market linkages: Evidence from the pre- and post-October 1987 period. Journal of Banking \& Finance, 17(1), 193-208. https://doi.org/10.1016/0378-4266(93)90088-U

Arshanapalli, B., Doukas, J., \& Lang, L. H. P. (1995). Pre and post-October 1987 stock market linkages between U.S. and Asian markets. Pacific-Basin Finance Journal, 3(1), 57-73. https://doi.org/10.1016/0927-538X(94)00025-3

Asgharian, H., Hess, W., \& Liu, L. (2013). A spatial analysis of international stock market linkages. $\begin{array}{llll}\text { Journal of Banking \& } \quad \text { Finance, } & 37(12), \quad 4738-4754 .\end{array}$ https://doi.org/10.1016/j.jbankfin.2013.08.015

Babecký, J., Komárek, L., \& Komárková, Z. (2013). Convergence of Returns on Chinese and Russian Stock Markets with World Markets: National and Sectoral Perspectives. National Institute Economic Review, 223(1), R16-R34. https://doi.org/10.1177/002795011322300103

Baumöhl, E., \& Výrost, T. (2010). Stock market integration: Granger causality testing with respect to nonsynchronous trading effects. Finance a Uver - Czech Journal of Economics and Finance, 60(5), 414-425. 
Bekaert, G., Erb, C. B., Harvey, C. R., \& Viskanta, T. E. (1998). Distributional Characteristics of Emerging Market Returns and Asset Allocation. The Journal of Portfolio Management, 24(2), 102 LP - 116. https://doi.org/10.3905/jpm.24.2.102

Bhattacharjee, S., \& Swaminathan, A. M. (2016). Stock Market Integration of India with Rest of the World: An Empirical Study. Indian Journal of Finance, 10(5). https://doi.org/10.17010/ijf\%2F2016\%2Fv10i5\%2F92934

Bhattacharya, S. N., Bhattacharya, M., \& Jha, S. K. (2020). Liquidity and Asset Pricing: Evidence from Indian Stock Market. Indian Journal of Finance and Banking, 4(1), 109-116. https://doi.org/10.46281/ijfb.v4i1.604

Bhunia, A., \& Das, A. (2012). Financial Market Integration : Empirical Evidence from India and Select South Asian Countries. International Journal of Scientific \& Engineering Research, 3(3), 1-6.

Birău, R., \& Trivedi, J. (2013). Emerging stock market integration and contagion in the context of global financial crisis. International Journal of Mathematical Models and Methods in Applied Sciences, 7(9), 828-836.

Brooks, R., \& Del Negro, M. (2004). The rise in comovement across national stock markets: market integration or IT bubble? Journal of Empirical Finance, 11(5), 659-680. https://doi.org/10.1016/j.jempfin.2003.08.001

Chancharat, S. (2009). Stock market Integration--An Overview 1. NIDA Economic Review, 4(2), $23-35$.

Chen, S. W., \& Shen, C. H. (2009). Can the nonlinear present value model explain the movement of stock prices? International Research Journal of Finance and Economics, 1(23), 155-170.

Chittedi, K. R. (2010). Global Stock Markets Development and Integration: with Special Reference to BRIC Countries. International Review of Applied Financial Issues \& Economics, 2(1), 18-36.

Click, R. W., \& Plummer, M. G. (2005). Stock market integration in ASEAN after the Asian financial crisis. Journal of Asian Economics, 16(1), 5-28. https://doi.org/10.1016/j.asieco.2004.11.018

Darrat, A. F., Elkhal, K., \& Hakim, S. R. (2000). On the Integration of Emerging Stock Markets in the Middle East. Journal of Economic Development, 25(2), 119-129.

Dickey, D. A., \& Fuller, W. A. (1979). Distribution of the Estimators for Autoregressive Time Series With a Unit Root. Journal of the American Statistical Association, 74(366), 427-431. https://doi.org/10.2307/2286348

Dickey, D. A., \& Fuller, W. A. (1981). Likelihood Ratio Statistics for Autoregressive Time Series with a Unit Root. Econometrica, 49(4), 1057-1072. https://doi.org/10.2307/1912517

Dorodnykh, E. (2014). Determinants of stock exchange integration: evidence in worldwide perspective. Journal of Economic Studies, 41(2), 292-316. https://doi.org/10.1108/JES-08-2012-0111 
Engle, R. F., \& Granger, C. W. J. (1987). Co-Integration and Error Correction : Representation , Estimation, and Testing Published by: The Econometric Society Stable. yet drift too far apart . Typically economic theory will propose forces which tend to. Econometrica, 55(2), 251-276.

Golder, U., Islam, M. N., \& Kayser, M. S. (2020). Impact of Foreign Exchange Reserve, Exchange Rate and Crude Oil Price on Dhaka Stock Exchange Index: An Empirical Evidence from Vector Error Correction Model. Indian Journal of Finance and Banking, 4(1), 134-143. https://doi.org/10.46281/ijfb.v4i1.633

Granger, C. W. J. (1983). Cointegrated variables and error correction models.

Granger, C. W. J. (1988). Causality, cointegration, and control. Journal of Economic Dynamics and Control, 12(2), 551-559. https://doi.org/10.1016/0165-1889(88)90055-3

Granger, C. W. J., \& Weiss, A. A. (1983). Time Series Analysis of Error-Correction Models. In S. KARLIN, T. AMEMIYA, \& L. E. O. A. B. T.-S. in E. GOODMAN Time Series, and Multivariate Statistics (Eds.), Studies in Econometrics, Time Series, and Multivariate Statistics (pp. 255-278). Academic Press. https://doi.org/10.1016/B978-0-12-398750-1.50018-8

Gupta, R., \& Guidi, F. (2012). Cointegration relationship and time varying co-movements among Indian and Asian developed stock markets. International Review of Financial Analysis, 21, 10-22. https://doi.org/10.1016/j.irfa.2011.09.001

Harvey, C. R. (1995). Predictable Risk and Returns in Emerging Markets. The Review of Financial Studies, 8(3), 773-816. https://doi.org/10.1093/rfs/8.3.773

Johansen, S. (1988). Statistical analysis of cointegration vectors. Journal of Economic Dynamics and Control, 12(2-3), 231-254. https://doi.org/10.1016/0165-1889(88)90041-3

Johansen, S. (1991). Estimation and Hypothesis Testing of Cointegration Vectors in Gaussian Vector Autoregressive Models. Econometrica, 59(6), 1551-1580. https://doi.org/10.2307/2938278

Johansen, S. (1995). Likelihood-Based Inference in Cointegrated Vector Autoregressive Models.

Johansen, S., \& Juselius, K. (1990). Maximum Likelihood Estimation and Inference on Cointegration - With Applications To the Demand for Money. Oxford Bulletin of Economics and Statistics, 52(2), 169-210. https://doi.org/10.1111/j.1468-0084.1990.mp52002003.x

Joshi, S. S. (2013). Correlation and Co-integration of BRIC Countries' Stock Markets. Indian Journal of Finance, 7(4). http://www.indianjournaloffinance.co.in/index.php/IJF/article/view/72131

Khan, T. A. (2011). Cointegration of International Stock Markets: An Investigation of Diversification Opportunities. Undergraduate Economic Review, $5(1), \quad 52$. http://digitalcommons.iwu.edu/uer/vol8/iss1/7/

Kiviet, J. F., \& Chen, Z. (2018). A critical appraisal of studies analyzing co-movement of international 
stock markets. Annals of Economics and Finance, 19(1), 151-196.

Kizys, R., \& Pierdzioch, C. (2009). Changes in the international comovement of stock returns and asymmetric macroeconomic shocks. Journal of International Financial Markets, Institutions and Money, 19(2), 289-305. https://doi.org/10.1016/j.intfin.2008.01.002

Masih, A. M. M., \& Masih, R. (1997). On the temporal causal relationship between energy consumption, real income, and prices: Some new evidence from Asian-energy dependent NICs Based on a multivariate cointegration/vector error-correction approach. Journal of Policy Modeling, 19(4), 417-440. https://doi.org/10.1016/S0161-8938(96)00063-4

Mitra, A., \& Bhattacharjee, K. (2015). Financial Interdependence of International Stock Markets: A Literature Review. Indian Journal of Finance, 9(5). https://doi.org/10.17010/ijf/2015/v9i5/71447

Modi, A., Patel, B., \& Patel, N. (2010). The study on co-movement of selected stock markets. International Research Journal of Finance and Economics, 47(47), 170-185.

Majid, M. S. A., Meera, A. K. M., Omar, M. A., \& Aziz, H. A. (2009). Dynamic linkages among ASEAN-5 emerging stock markets. International Journal of Emerging Markets, 4(2), 160-184. https://doi.org/10.1108/17468800910945783

Nath, G. C., \& Verma, S. (2003). Study of common stochastic trend and co-integration in the emerging markets: A case study of India, Singapore and Taiwan. NSE Research Paper, 72.

Mukherjee, K. N., \& Mishra, R. K. (2005). Stock Market Interlinkages: A Study of Indian and World Equity Markets. Indian Journal of Commerce, 58(1).

Nautiyal, N., \& Kavidayal, P. C. (2018). A VECM Approach to Explain Dynamic Alliance Between Stock Markets. Indian Journal of Finance, 12(11). https://doi.org/10.17010/ijf/2018/v12i11/138203

Okon, E. O. (2018). Development and Terrorism in Nigeria: Co-Integration and Causality Analysis of Macroeconomic Factors. Indian Journal of Finance and Banking, 2(1), 1-33. https://doi.org/10.46281/ijfb.v2i1.90

Park, C.-Y., \& Lee, J.-W. (2011). Financial Integration in Emerging Asia: Challenges and Prospects. Asian Economic Policy Review, 6(2), 176-198. https://doi.org/10.1111/j.17483131.2011.01193.x

Patel, S. A. (2014). Causal and Co-integration Analysis of Indian and Selected Asian Stock Markets. Drishtikon: A Management Journal, 5(1), 37-52.

Phuan, S.M., Lim, K.P., \& Ooi, A.Y. (2009). Financial Liberalization and Stock Markets Integration for Asean-5 Countries. International Business Research, 2(1), 100-111. https://doi.org/10.5539/ibr.v2n1p100 
Raju, G. A., \& Khanapuri, H. R. (2009). Regional Integration of Emerging Stock Markets in Asia: Implications for International Investors. The Journal of Investing, 18(3), 31-39. https://doi.org/10.3905/JOI.2009.18.3.031

Roll, R. (1989). Price Volatility, International Market Links, and Their Implications for Regulatory Policies. In F. R. Edwards (Ed.), Regulatory Reform of Stock and Futures Markets: A Special Issue of the Journal of Financial Services Research (pp. 113-148). Springer Netherlands. https://doi.org/10.1007/978-94-009-2193-1_10

Scheicher, M. (2001). The comovements of stock markets in Hungary, Poland and the Czech Republic. International Journal of Finance \& Economics, 6(1), 27-39. https://doi.org/https://doi.org/10.1002/ijfe.141

Shahzad, S. J. H., Kanwal, M., Ahmed, T., \& Ur Rehman, M. (2016). Relationship between developed, European and South Asian stock markets: a multivariate analysis. South Asian Journal of Global Business Research, 5(3), 385-402. https://doi.org/10.1108/SAJGBR-01-2015-0002

Sharma, A., \& Seth, N. (2012). Literature review of stock market integration: a global perspective. Qualitative Research in Financial Markets, 4(1), 84-122. https://doi.org/10.1108/17554171211213568

Thalassinos, E., \& Thalassinos, P. E. (2006). Stock Markets' Integration Analysis. European Research Studies, 9((3-4)), 3-13. https://www.um.edu.mt/library/oar//handle/123456789/31492

Wang, P., \& Moore, T. (2008). Stock Market Integration for the Transition Economies: Time-Varying Conditional Correlation Approach. The Manchester School, 76(s1), 116-133. https://doi.org/10.1111/j.1467-9957.2008.01083.x

Yeoh, B. K., Hooy, C. W., \& Arsad, Z. (2010). Time-varying world integration of the malaysian stock market: A Kalman filter approach. Asian Academy of Management Journal of Accounting and Finance, 6(2), 1-17.

Appendix A. Results of Bi-directional Causality

\begin{tabular}{|c|c|c|c|c|}
\hline Indices & \multicolumn{4}{|c|}{ Bi-Directional Causality with an Index } \\
\hline Time Period & 2005-2009 & $2010-2014$ & $2015-2018$ & 2005-2018 \\
\hline AEX & $\begin{array}{l}\text { BEL20, BIST100, } \\
\text { CAC40, DAX, } \\
\text { GSPC S\&P500, } \\
\text { IBOVESPA, IPC, } \\
\text { MERVAL, } \\
\text { NASDAQ, NYSE, } \\
\text { S\&P TSX, SMI, } \\
\text { STOXX50, (13) }\end{array}$ & $\begin{array}{l}\text { BEL20, BIST100, } \\
\text { CAC40, DAX, } \\
\text { DJIA, } \\
\text { S\&P500, } \\
\text { IBOVESPA, IPC, } \\
\text { MERVAL, } \\
\text { NASDAQ, NYSE, } \\
\text { S\&P TSX, SMI } \\
(\mathbf{1 3 )}\end{array}$ & $\begin{array}{l}\text { BEL20, CAC40, } \\
\text { DAX, DJIA, } \\
\text { GSPC S\&P500, } \\
\text { IBOVESPA, IPC, } \\
\text { MERVAL, } \\
\text { NASDAQ, NYSE, } \\
\text { S\&P TSX, SMI, } \\
\text { STOXX50 (13) }\end{array}$ & $\begin{array}{l}\text { BEL20, } \\
\text { DAX, } \\
\text { S\&P500, } \\
\text { IBOVESPA, } \\
\text { MERVAL, } \\
\text { NASDAQ, } \\
\text { S\&P TSX, SMI (11) }\end{array}$ \\
\hline
\end{tabular}




\begin{tabular}{|c|c|c|c|c|}
\hline ATX & $\begin{array}{lr}\text { GSPC } & \text { S\&P500, } \\
\text { MERVAL, } & \\
\text { NASDAQ, } & \text { NYSE, } \\
\text { OSE, } & \text { RTSI } \\
\text { RUSSIA, } & \text { S\&P } \\
\text { TSX, SENSEX, (8) }\end{array}$ & $\begin{array}{lr}\text { GSPC } & \text { S\&P500, } \\
\text { IPC, } & \text { MERVAL, } \\
\text { NASDAQ, NYSE, } \\
\text { OSE, } \\
\text { RUSSIA, } & \text { RTSI } \\
\text { TSX, SENSEX (9) }\end{array}$ & $\begin{array}{lr}\text { GSPC } & \text { S\&P500, } \\
\text { MERVAL, } \\
\text { NASDAQ, NYSE, } \\
\text { OSE, } \\
\text { RUSSIA, } \\
\begin{array}{lr}\text { TSX, SEP } \\
\text { (8) }\end{array}\end{array}$ & $\begin{array}{lr}\text { GSPC } & \text { S\&P500, } \\
\text { MERVAL, } & \\
\text { NASDAQ, } & \text { NYSE, } \\
\text { OSE, } & \text { RTSI } \\
\text { RUSSIA, S\&P TSX, } & \text { SENSEX (8) }\end{array}$ \\
\hline BEL 20 & $\begin{array}{l}\text { AEX, CAC40, } \\
\text { GSPC S\&P500, } \\
\text { IBOVESPA, } \\
\text { MERVAL, } \\
\text { NASDAQ, NYSE, } \\
\text { S\&P TSX, } \\
\text { STOXX50 (9) }\end{array}$ & $\begin{array}{l}\text { AEX, CAC40, } \\
\text { GSPC S\&P500, } \\
\text { IBOVESPA, } \\
\text { MERVAL, } \\
\text { NASDAQ, NYSE, } \\
\text { S\&P TSX, } \\
\text { STOXX50 (9) }\end{array}$ & $\begin{array}{l}\text { AEX, CAC40, } \\
\text { GSPC S\&P500, } \\
\text { IBOVESPA, } \\
\text { MERVAL, } \\
\text { NASDAQ, NYSE, } \\
\text { S\&P TSX, } \\
\text { STOXX50 (9) }\end{array}$ & $\begin{array}{lr}\text { AEX, } & \text { CAC40, } \\
\text { GSPC S\&P500, } & \text { S\&OVESPA, } \\
\text { MERVAL, } & \\
\text { NASDAQ, } & \text { NYSE, } \\
\text { S\&P } & \text { TSX, } \\
\text { STOXX50, (9) }\end{array}$ \\
\hline BIST 100 & AEX, AORD (2) & AEX (1) & & \\
\hline CAC 40 & $\begin{array}{lr}\text { AEX, } & \text { BEL20, } \\
\text { DAX, } & \text { GSPC } \\
\text { S\&P500, } & \\
\text { NASDAQ, NYSE, } \\
\text { OMX, OSE, S\&P } \\
\text { TSX, } \\
\text { STOXX50 (11) }\end{array}$ & $\begin{array}{lr}\text { AEX, } & \text { BEL20, } \\
\text { DAX, } & \text { GSPC } \\
\text { S\&P500, } & \\
\text { NASDAQ, NYSE, } \\
\text { OMX, OSE, S\&P } \\
\text { TSX, r SMI, } \\
\text { STOXX50 (11) }\end{array}$ & $\begin{array}{lr}\text { AEX, } & \text { BEL20, } \\
\text { DAX, } & \text { GSPC } \\
\text { S\&P500, } & \\
\text { NASDAQ, NYSE, } \\
\text { OSE, S\&P TSX, } \\
\text { SMI, STOXX50 } \\
(\mathbf{1 0 )}\end{array}$ & 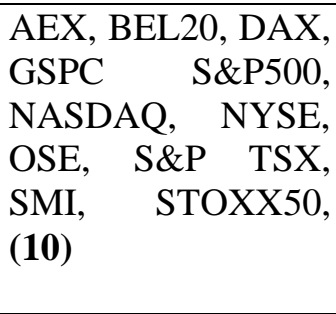 \\
\hline DAX & $\begin{array}{lr}\text { AEX, } & \text { CAC40, } \\
\text { FTSE100, } & \text { GSPC } \\
\text { S\&P500, } & \text { IBEX, } \\
\text { KOSPI, } & \text { SENSEX } \\
(7) & \end{array}$ & $\begin{array}{l}\text { AEX, CAC40, } \\
\text { FTSE100, IBEX, } \\
\text { SENSEX (5) }\end{array}$ & $\begin{array}{l}\text { AEX, } \\
\text { FTSE100, GAC40, } \\
\text { S\&P500, IBEX, } \\
\text { SENSEX (6) }\end{array}$ & $\begin{array}{lr}\text { AEX, } & \text { CAC40, } \\
\text { FTSE100, IBEX, } \\
\text { SENSEX (5) }\end{array}$ \\
\hline DJIA & RTSI RUSSIA (1) & $\begin{array}{ll}\text { AEX, } & \text { RTSI } \\
\text { RUSSIA (1) }\end{array}$ & $\begin{array}{ll}\text { AEX, } & \text { RTSI } \\
\text { RUSSIA (2) }\end{array}$ & RTSI RUSSIA (1) \\
\hline FTSE100 & $\begin{array}{lr}\text { DAX, } & \text { GSPC } \\
\text { S\&P500, } & \text { IBEX, } \\
\text { IBOVESPA, IPC, } \\
\text { NASDAQ, NYSE, } \\
\text { OSE, S\&P } & \text { TSX, } \\
\text { SMI (10) } & \end{array}$ & $\begin{array}{l}\text { DAX, GSPC } \\
\text { S\&P500, } \\
\text { IBOVESPA, IPC, } \\
\text { NASDAQ, NYSE, } \\
\text { OSE, S\&P TSX, } \\
\text { SMI (9) }\end{array}$ & $\begin{array}{l}\text { DAX, GSPC } \\
\text { S\&P500, } \\
\text { IBOVESPA, IPC, } \\
\text { NASDAQ, NYSE, } \\
\text { OSE, S\&P TSX, } \\
\text { SMI (9) }\end{array}$ & $\begin{array}{lr}\text { DAX, } & \text { GSPC } \\
\text { S\&P500, } & \\
\text { IBOVESPA, } & \text { IPC, } \\
\text { NASDAQ, } & \text { NYSE, } \\
\text { OSE, S\&P } & \text { TSX, } \\
\text { SMI (9) } & \end{array}$ \\
\hline $\begin{array}{l}\text { GSPC } \\
\text { S\&P500 }\end{array}$ & 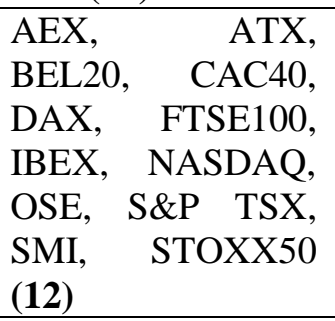 & $\begin{array}{l}\text { AEX, } \\
\text { BEL20, CAC40, } \\
\text { FTSE100, IBEX, } \\
\text { NASDAQ, OSE, } \\
\text { S\&P TSX, SMI, } \\
\text { STOXX50 (11) }\end{array}$ & $\begin{array}{lr}\text { AEX, } & \text { ATX, } \\
\text { BEL20, } & \text { CAC40, } \\
\text { DAX, FTSE100, } \\
\text { IBEX, NASDAQ, } \\
\text { OSE, S\&P TSX, } \\
\text { SMI, STOXX50, } \\
(\mathbf{1 2 )}\end{array}$ & $\begin{array}{l}\text { AEX, ATX, BEL20, } \\
\text { CAC40, FTSE100, } \\
\text { IBEX, NASDAQ, } \\
\text { OSE, S\&P TSX, } \\
\text { SMI, STOXX50 (11) }\end{array}$ \\
\hline IBEX & $\begin{array}{l}\text { BEL20, DAX, } \\
\text { GSPC S\&P500, } \\
\text { NASDAQ, NYSE, } \\
\text { OSE, S\&P TSX, } \\
\text { STOXX50 (8) }\end{array}$ & $\begin{array}{l}\text { DAX, } \\
\text { S\&P500, } \\
\text { NASDAQ, NYSE, } \\
\text { OSE, S\&P TSX, } \\
\text { STOXX50 (7) }\end{array}$ & $\begin{array}{l}\text { BEL20, } \\
\text { GSPC } \\
\text { N\&P500, } \\
\text { NASDAQ, NYSE, } \\
\text { OSE, S\&P TSX } \\
(7)\end{array}$ & $\begin{array}{lr}\text { DAX, } & \text { GSPC } \\
\text { S\&P500 NASDAQ, } & \text { NASE, OSE, S\&P } \\
\text { NYSE } \\
\text { TSX (6) }\end{array}$ \\
\hline IBOVESPA & $\begin{array}{l}\text { AEX, BEL20, } \\
\text { FTSE100, } \\
\text { STOXX50 (4) }\end{array}$ & $\begin{array}{l}\text { AEX, BEL20, } \\
\text { FTSE100, } \\
\text { STOXX50 (4) }\end{array}$ & $\begin{array}{l}\text { AEX, BEL20, } \\
\text { FTSE100, } \\
\text { STOXX50 (4) }\end{array}$ & $\begin{array}{l}\text { AEX, } \\
\text { FTSE100, } \\
\text { STOXX50 (4) }\end{array}$ \\
\hline
\end{tabular}




\begin{tabular}{|c|c|c|c|c|}
\hline IPC & $\begin{array}{ll}\text { AEX, } & \text { FTSE100, } \\
\text { OSE (3) } & \end{array}$ & $\begin{array}{l}\text { AEX, ATX, } \\
\text { FTSE100, OSE (4) }\end{array}$ & $\begin{array}{l}\text { AEX, FTSE100, } \\
\text { OSE (3) }\end{array}$ & $\begin{array}{ll}\text { AEX, } & \text { FTSE100, } \\
\text { OSE (3) } & \end{array}$ \\
\hline MERVAL & $\begin{array}{l}\text { AEX, ATX, BEL20 } \\
\text { (3) }\end{array}$ & $\begin{array}{ll}\text { AEX, } & \text { ATX, } \\
\text { BEL20 (3) } & \end{array}$ & $\begin{array}{ll}\text { AEX, } & \text { ATX, } \\
\text { BEL20 (3) } & \end{array}$ & $\begin{array}{l}\text { AEX, ATX, BEL20, } \\
\text { (3) }\end{array}$ \\
\hline NASDAQ & $\begin{array}{lr}\text { AEX, } & \text { ATX, } \\
\text { BEL20, } & \text { CAC40, } \\
\text { FTSE100, } & \text { GSPC } \\
\text { S\&P500, } & \text { IBEX, } \\
\text { OSE, S\&P TSX, } & \text { TSXX (10) }\end{array}$ & $\begin{array}{lr}\text { AEX, } & \text { ATX, } \\
\text { BEL20, } & \text { CAC40, } \\
\text { FTSE100, } & \text { GSPC } \\
\text { S\&P500, IBEX, } \\
\text { OSE, S\&P TSX, } \\
\text { STOXX50 (10) }\end{array}$ & $\begin{array}{lr}\text { AEX, } & \text { ATX, } \\
\text { BEL20, } & \text { CAC40, } \\
\text { FTSE100, GSPC } \\
\text { S\&P500, IBEX, } \\
\text { OSE, S\&P TSX, } \\
\text { STOXX50 (10) }\end{array}$ & $\begin{array}{l}\text { AEX, ATX, BEL20, } \\
\text { CAC40, } \\
\text { GSSE100, } \\
\text { IBEX, } \\
\text { IS\&P500, } \\
\text { TSX, } \\
(\mathbf{1 0})\end{array}$ \\
\hline NYSE & $\begin{array}{lr}\text { AEX, } & \text { ATX, } \\
\text { BEL20, } & \text { CAC40, } \\
\text { FTSE100, IBEX, } \\
\text { OMX, } \\
\text { S\&PTSX, } \\
\text { STOXX50 (10) }\end{array}$ & $\begin{array}{lr}\text { AEX, } & \text { ATX, } \\
\text { BEL20, } & \text { CAC40, } \\
\text { FTSE100, IBEX, } \\
\text { OMX, } \\
\text { S\&PTSX, } \\
\text { STOXX50 } \\
\text { (10) }\end{array}$ & $\begin{array}{lr}\text { AEX, } & \text { ATX, } \\
\text { BEL20, } & \text { CAC40, } \\
\text { FTSE100, IBEX, } \\
\text { OMX, } \\
\text { S\&PTSX, } \\
\text { STOXX50 (10) }\end{array}$ & $\begin{array}{l}\text { AEX, ATX, BEL20, } \\
\text { CAC40, FTSE100, } \\
\text { IBEX, OMX, OSE, } \\
\text { S\&PTSX, } \\
\text { STOXX50(10) }\end{array}$ \\
\hline OMX & $\begin{array}{l}\text { CAC40, NYSE, } \\
\text { OSE, S\&P TSX (4) }\end{array}$ & $\begin{array}{l}\text { CAC40, NYSE, } \\
\text { OSE, S\&P TSX } \\
\text { (4) }\end{array}$ & $\begin{array}{l}\text { NYSE, OSE, S\&P } \\
\text { TSX (3) }\end{array}$ & $\begin{array}{l}\text { NYSE, OSE, S\&P } \\
\text { TSX (3) }\end{array}$ \\
\hline OSE & $\begin{array}{lr}\text { AORD, } & \text { BEL20, } \\
\text { CAC40, } & \text { FTSE100, } \\
\text { GSPC } & \text { S\&P500, } \\
\text { IBEX, } & \text { IPC, } \\
\text { NASDAQ, } & \text { NYSE, } \\
\text { OMX, } & \text { RTSI } \\
\text { RUSSIA, } & \text { S\&P } \\
\text { TSX, } & \text { SENSEX, } \\
\text { STOXX50 (14) }\end{array}$ & $\begin{array}{lr}\text { AORD, } & \text { BEL20, } \\
\text { CAC40, FTSE100, } \\
\text { GSPC } & \text { S\&P500, } \\
\text { IBEX, } & \text { IPC, } \\
\text { NASDAQ, NYSE, } \\
\text { OMX, r r } \\
\text { RUSSIA, } & \text { S\&P } \\
\text { TSX, SENSEX, } \\
\text { STOXX50 (14) }\end{array}$ & $\begin{array}{lr}\text { AORD, } & \text { BEL20, } \\
\text { CAC40, FTSE100, } \\
\text { GSPC } & \text { S\&P500, } \\
\text { IBEX, } & \text { IPC, } \\
\text { NASDAQ, NYSE, } & \text { RMX, rS } \\
\text { RUSSIA, } & \text { S\&P } \\
\text { TSX, SENSEX, } & \text { STOXX50 (14) } \\
\end{array}$ & $\begin{array}{lr}\text { AORD, } & \text { BEL20, } \\
\text { CAC40, } & \text { FTSE100, } \\
\text { GSPC } & \text { S\&P500, } \\
\text { IBEX, } & \text { IPC, } \\
\text { NASDAQ, } & \text { NYSE, } \\
\text { OMX, r } & \text { RTSI } \\
\text { RUSSIA, S\&P TSX, } & \text { SENSEX, } \\
\text { STOXX50 (14) }\end{array}$ \\
\hline RTSI RUSSIA & $\begin{array}{ll}\text { ATX, DJIA, OSE, } \\
\text { S\&P } \\
\text { SENSEX, SMI }(\mathbf{6})\end{array}$ & $\begin{array}{lr}\text { ATX, DJIA, OSE, } \\
\text { S\&P r TSX, } \\
\text { SENSEX, SMI (6) }\end{array}$ & $\begin{array}{lr}\text { ATX, DJIA, OSE, } \\
\text { S\&P r TSX, } \\
\text { SENSEX, SMI (6) }\end{array}$ & $\begin{array}{ll}\text { ATX, DJIA, OSE, } & \text { TSX, } \\
\text { S\&P } & \text { TENSEX, SMI (6) } \\
\text { SEN }\end{array}$ \\
\hline S\& P TSX & $\begin{array}{lr}\text { AEX, } & \text { ATX, } \\
\text { BEL20, } & \text { CAC40, } \\
\text { FTSE100, } & \text { GSPC } \\
\text { S\&P500, } & \text { IBEX, } \\
\text { NASDAQ, } & \text { NYSE, } \\
\text { OMX, OSE, RTSI } \\
\text { RUSSIA, } & \text { SMI, } \\
\text { STOXX (14) } & \\
\end{array}$ & 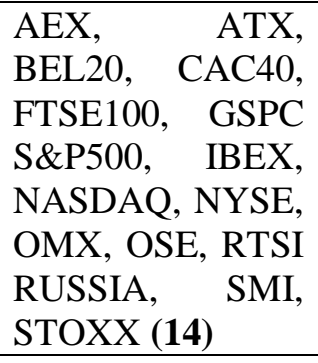 & 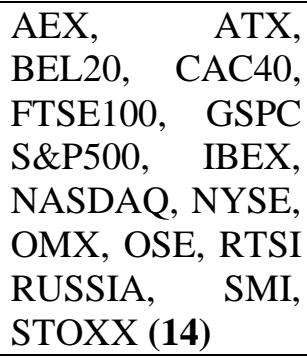 & $\begin{array}{l}\text { AEX, ATX, BEL20, } \\
\text { CAC40, FTSE100, } \\
\text { GSPC } \\
\text { IBEX, NAP00, } \\
\text { NYSE, OMX, OSE, } \\
\text { RTSI RUSSIA, SMI, } \\
\text { STOXX (14) }\end{array}$ \\
\hline SENSEX & $\begin{array}{l}\text { ATX, DAX, OSE, } \\
\text { RTSI RUSSIA, } \\
\text { S\&P TSX (5) }\end{array}$ & $\begin{array}{l}\text { ATX, DAX, OSE, } \\
\text { RTSI RUSSIA, } \\
\text { S\&P TSX (5) }\end{array}$ & $\begin{array}{l}\text { ATX, DAX, OSE, } \\
\text { RTSI RUSSIA, } \\
\text { S\&P TSX (5) }\end{array}$ & $\begin{array}{l}\text { ATX, DAX, OSE, } \\
\text { RTSI RUSSIA, S\&P } \\
\text { TSX (5) }\end{array}$ \\
\hline SMI & $\begin{array}{lr}\text { AEX, } & \text { CAC40, } \\
\text { FTSE100, } & \text { GSPC } \\
\text { S\&P500, } & \text { RTSI } \\
\text { RUSSIA, } & \text { SP TSX } \\
(\mathbf{5}) & \\
\end{array}$ & $\begin{array}{lr}\text { AEX, } & \text { CAC40, } \\
\text { FTSE100, } & \text { GSPC } \\
\text { S\&P500, } & \text { RTSI } \\
\text { RUSSIA, } & \text { S\&P } \\
\text { TSX (5) } & \\
\end{array}$ & $\begin{array}{lr}\text { AEX, } & \text { CAC40, } \\
\text { FTSE100, } & \text { GSPC } \\
\text { S\&P500, } & \text { RTSI } \\
\text { RUSSIA, } & \text { S\&P } \\
\text { TSX (5) } & \\
\end{array}$ & $\begin{array}{lr}\text { AEX, } & \text { CAC40, } \\
\text { FTSE100, } & \text { GSPC } \\
\text { S\&P500, } & \text { RTSI } \\
\text { RUSSIA, } & \text { S\&P TSX } \\
(\mathbf{5}) & \end{array}$ \\
\hline STOXX50 & $\begin{array}{lr}\text { AEX, } & \text { BEL20, } \\
\text { CAC40, } & \text { GSPC } \\
\text { S\&P500, } & \text { IBEX, }\end{array}$ & $\begin{array}{ll}\text { BEL20, } & \text { CAC40, } \\
\text { GSPC } & \text { S\&P500, } \\
\text { IBEX, } & \\
\end{array}$ & $\begin{array}{lr}\text { AEX, } & \text { BEL20, } \\
\text { CAC40, } & \text { GSPC } \\
\text { S\&P500, } & \\
\end{array}$ & $\begin{array}{l}\text { BEL20, CAC40, } \\
\text { GSPC S\&P500, } \\
\text { IBOVESPA, }\end{array}$ \\
\hline
\end{tabular}




\begin{tabular}{|l|l|l|l|l|}
\hline & IBOVESPA, & IBOVESPA, & IBOVESPA, & NASDAQ, NYSE, \\
NASDAQ, NYSE, & NASDAQ, NYSE, & NASDAQ, NYSE, & OSE, S\&P TSX (8) \\
OSE, S\&P TSX & $\begin{array}{l}\text { OSE, S\&P TSX } \\
\mathbf{( 1 0 )}\end{array}$ & $\begin{array}{l}\text { OSE, S\&P TSX } \\
\mathbf{( 9 )}\end{array}$ & \\
\hline
\end{tabular}

Appendix B. Results of Uni-directional Causality

\begin{tabular}{|c|c|c|c|c|}
\hline Indices & \multicolumn{4}{|c|}{ Uni-Directional Causality with an Index } \\
\hline Time Period & $2005-2009$ & $2010-2014$ & $2015-2018$ & $2005-2018$ \\
\hline AEX & $\begin{array}{l}\text { ATX, FTSE100, } \\
\text { IBEX OMX, OSE, } \\
\text { RTSI RUSSIA, } \\
\text { SENSEX (7) }\end{array}$ & $\begin{array}{lr}\text { ATX, } & \text { IBEX, } \\
\text { FTSE100 } & \text { OMX, } \\
\text { OSE, } & \text { RTSI } \\
\text { RUSSIA, } & \\
\text { SENSEX (7) } & \end{array}$ & $\begin{array}{lr}\text { ATX, IBEX, OMX, } \\
\text { OSE, } \\
\text { RUSSIA, SENSEX } \\
(\mathbf{6})\end{array}$ & $\begin{array}{lr}\text { ATX, IBEX, OMX, } \\
\text { OSE, } \\
\text { RUSSIA, SENSEX } \\
\text { (6) }\end{array}$ \\
\hline ATX & $\begin{array}{l}\text { BIST100, DJIA, } \\
\text { STOXX50 (3) }\end{array}$ & $\begin{array}{l}\text { DJIA, STOXX50, } \\
\text { SMI (3) }\end{array}$ & DJIA, SMI (2) & DJIA (1) \\
\hline BEL 20 & $\begin{array}{l}\text { ATX, BIST100, } \\
\text { DJIA, FTSE100, } \\
\text { OMX, OSE, RTSI } \\
\text { RUSSIA, } \\
\text { SENSEX (8) }\end{array}$ & $\begin{array}{lr}\text { ATX, } & \text { DJIA, } \\
\text { FTSE100, } & \text { OMX, } \\
\text { OSE, } & \text { RTSI } \\
\text { RUSSIA, } & \\
\text { SENSEX (7) }\end{array}$ & $\begin{array}{l}\text { ATX, BIST100, } \\
\text { DJIA, FTSE100, } \\
\text { OMX, OSE, RTSI } \\
\text { RUSSIA, SENSEX } \\
(\mathbf{8})\end{array}$ & $\begin{array}{lr}\text { ATX, } & \text { DJIA, } \\
\text { FTSE100, } & \text { OMX, } \\
\text { OSE, } & \text { RTSI } \\
\text { RUSSIA, } & \text { SENSEX } \\
\text { (7) } & \end{array}$ \\
\hline BIST 100 & $\begin{array}{l}\text { MERVAL, } \\
\text { STOXX50 (2) }\end{array}$ & $\begin{array}{l}\text { MERVAL, } \\
\text { STOXX50 (2) }\end{array}$ & $\begin{array}{l}\text { MERVAL, } \\
\text { STOXX50 (2) }\end{array}$ & $\begin{array}{l}\text { MERVAL, } \\
\text { STOXX50 (2) }\end{array}$ \\
\hline CAC 40 & $\begin{array}{l}\text { ATX, DJIA, IBEX, } \\
\text { RTSI RUSSIA, } \\
\text { SENSEX (5) }\end{array}$ & $\begin{array}{l}\text { ATX, } \\
\text { IBEX, } \\
\text { RUSIA, } \\
\text { SENSEX }\end{array}$ & $\begin{array}{l}\text { ATX, IBEX, RTSI } \\
\text { RUSSIA, SENSEX } \\
\text { (4) }\end{array}$ & $\begin{array}{l}\text { ATX, IBEX, RTSI } \\
\text { RUSSIA, SENSEX } \\
\text { (4) }\end{array}$ \\
\hline DAX & $\begin{array}{l}\text { ATX, } \\
\text { BIST100, DJ20, } \\
\text { GSPC S\&P500, } \\
\text { IBOVESPA, IPC, } \\
\text { MERVAL, } \\
\text { NASDAQ, NYSE, } \\
\text { OMX, OSE, RTSI } \\
\text { RUSSIA, S\&P } \\
\text { TSX, STOXX50 } \\
(\mathbf{1 5 )}\end{array}$ & $\begin{array}{l}\text { ATX, } \\
\text { DJIA, } \\
\text { S\&P500, } \\
\text { IBOVESPA, IPC, } \\
\text { MERVAL, } \\
\text { NASDAQ, NYSE, } \\
\text { OMX, OSE, RTSI } \\
\text { RUSSIA, S\&P } \\
\text { TSX, STOXX50 } \\
(\mathbf{1 4 )}\end{array}$ & $\begin{array}{l}\text { ATX, } \\
\text { BIST100, } \\
\text { GSPC DJIA, } \\
\text { IBOVESPA, IPC500, } \\
\text { MERVAL, } \\
\text { NASDAQ, NYSE, } \\
\text { OMX, OSE, RTSI } \\
\text { RUSSIA, S\&P TSX, } \\
\text { STOXX50 (15) }\end{array}$ & $\begin{array}{lr}\text { ATX, } & \text { BEL20, } \\
\text { DJIA, } & \text { GSPC } \\
\text { S\&P500, } & \\
\text { IBOVESPA, } & \text { IPC, } \\
\text { MERVAL, } & \\
\text { NASDAQ, } & \text { NYSE, } \\
\text { OMX, OSE, } & \text { RTSI } \\
\text { RUSSIA, } & \text { S\&P } \\
\text { TSX, STOXX50 } \\
(\mathbf{1 4 )}\end{array}$ \\
\hline DJIA & $\begin{array}{l}\text { NASDAQ, NYSE, } \\
\text { SENSEX, } \\
\text { STOXX50 (4) }\end{array}$ & $\begin{array}{l}\text { NASDAQ, NYSE, } \\
\text { SENSEX, } \\
\text { STOXX50 (4) }\end{array}$ & $\begin{array}{l}\text { NASDAQ, NYSE, } \\
\text { SENSEX (3) }\end{array}$ & $\begin{array}{l}\text { NASDAQ, NYSE, } \\
\text { SENSEX (3) }\end{array}$ \\
\hline FTSE100 & $\begin{array}{l}\text { ATX, OMX, RTSI } \\
\text { RUSSIA, } \\
\text { SENSEX (4) }\end{array}$ & $\begin{array}{lr}\text { ATX, } & \text { DJIA, } \\
\text { OMX, } & \text { RTSI } \\
\text { RUSSIA, } & \\
\text { SENSEX (5) }\end{array}$ & $\begin{array}{l}\text { ATX, DJIA, OMX, } \\
\text { RTSI RUSSIA, } \\
\text { SENSEX (5) }\end{array}$ & $\begin{array}{l}\text { ATX, OMX, RTSI } \\
\text { RUSSIA, SENSEX } \\
\text { (4) }\end{array}$ \\
\hline $\begin{array}{l}\text { GSPC } \\
\text { S\&P500 }\end{array}$ & $\begin{array}{l}\text { IBOVESPA, DJIA, } \\
\text { MERVAL, OMX. } \\
\text { RTSI RUSSIA, } \\
\text { SENSEX (6) }\end{array}$ & $\begin{array}{l}\text { IBOVESPA, } \\
\text { DJIA, MERVAL, } \\
\text { OMX. RTSI } \\
\text { RUSSIA, } \\
\text { SENSEX (6) }\end{array}$ & $\begin{array}{l}\text { MERVAL, OMX. } \\
\text { RTSI RUSSIA, } \\
\text { SENSEX (4) }\end{array}$ & $\begin{array}{l}\text { MERVAL, OMX. } \\
\text { RTSI RUSSIA, } \\
\text { SENSEX (4) }\end{array}$ \\
\hline
\end{tabular}




\begin{tabular}{|c|c|c|c|c|}
\hline IBEX & $\begin{array}{l}\text { ATX, BIST100, } \\
\text { DJIA, OMX, RTSI } \\
\text { RUSSIA, } \\
\text { SENSEX (6) }\end{array}$ & $\begin{array}{lr}\text { ATX, } & \text { BIST100, } \\
\text { DJIA, } & \text { RTSI } \\
\text { RUSSIA, } & \\
\text { SENSEX (5) }\end{array}$ & $\begin{array}{l}\text { ATX, DJIA, OMX, } \\
\text { RTSI RUSSIA, } \\
\text { SENSEX (5) }\end{array}$ & $\begin{array}{l}\text { ATX, DJIA, RTSI } \\
\text { RUSSIA, SENSEX } \\
\text { (4) }\end{array}$ \\
\hline IBOVESPA & 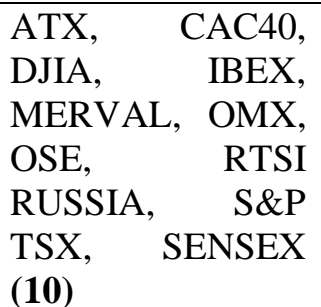 & $\begin{array}{lr}\text { ATX, } & \text { CAC40, } \\
\text { DJIA, } & \text { IBEX, } \\
\text { MERVAL, OMX, } & \text { OSE, } \\
\text { OSE } & \text { RTSI } \\
\text { RUSSIA, } & \text { S\&P, } \\
\text { (10) } & \end{array}$ & $\begin{array}{lr}\text { ATX, } & \text { CAC40, } \\
\text { DJIA, } & \text { IBEX, } \\
\text { MERVAL, } & \text { OMX, } \\
\text { OSE, } & \text { RTSI } \\
\text { RUSSIA, S\&P TSX, } & \text { SENSEX (10) }\end{array}$ & $\begin{array}{lr}\text { ATX, } & \text { CAC40, } \\
\text { DJIA, } & \text { IBEX, } \\
\text { MERVAL, } & \text { OMX, } \\
\text { OSE, } & \text { RTSI } \\
\text { RUSSIA, } & \text { S\&P } \\
\text { TSX, SENSEX (10) }\end{array}$ \\
\hline IPC & $\begin{array}{l}\text { ATX, } \\
\text { CAC40, IBE20, } \\
\text { IBOVESPA, } \\
\text { MERVAL, NYSE, } \\
\text { OMX, rTSI } \\
\text { RUSSIA, S\&P } \\
\text { TSX, SENSEX, } \\
\text { STOXX50 (12) }\end{array}$ & $\begin{array}{lr}\begin{array}{l}\text { ATX, } \\
\text { CAC40, }\end{array} & \text { IBEX, } \\
\text { IBOVESPA, } \\
\text { MERVAL, } \\
\text { NYSE, OMX, } \\
\text { RTSI RUSSIA, } \\
\text { S\&P r TSX, } \\
\text { SENSEX, } \\
\text { STOXX50 (12) }\end{array}$ & $\begin{array}{lr}\text { ATX, } & \text { BEL20, } \\
\text { CAC40, IBEX, } & \text { IBOVESPA, } \\
\text { MERVAL, NYSE, } & \text { NMX, } \\
\text { RTSIS } & \text { RUSS } \\
\text { SENSEX, TSX, } & \\
\text { STOXX50 (12) }\end{array}$ & $\begin{array}{lr}\text { ATX, } & \text { BEL20, } \\
\text { CAC40, } & \text { IBEX, } \\
\text { IBOVESPA, } \\
\text { MERVAL, } \\
\text { OMYSE, } \\
\text { RUSSIA, } \\
\text { TSX, STSI } \\
\text { STOXX50 }\end{array}$ \\
\hline MERVAL & $\begin{array}{l}\text { CAC40, DJIA, } \\
\text { FTSE100, IBEX, } \\
\text { OMX, OSE, S\&P } \\
\text { TSX, SENSEX, (8) }\end{array}$ & $\begin{array}{l}\text { CAC40, } \\
\text { FTSE100, IBEX, } \\
\text { OMX, OSE, S\&P } \\
\text { TSX, SENSEX, } \\
\text { STOXX50 (8) }\end{array}$ & $\begin{array}{l}\text { CAC40, DJIA, } \\
\text { FTSE100, IBEX, } \\
\text { OMX, OSE, S\&P } \\
\text { TSX, SENSEX, (8) }\end{array}$ & $\begin{array}{l}\text { CAC40, DJIA, } \\
\text { FTSE100, IBEX, } \\
\text { OMX, OSE, S\&P } \\
\text { TSX, SENSEX, (8) }\end{array}$ \\
\hline NASDAQ & $\begin{array}{l}\text { IBOVESPA, } \\
\text { MERVAL, OMX, } \\
\text { RTSI RUSSIA, } \\
\text { SENSEX (5) }\end{array}$ & $\begin{array}{l}\text { IBOVESPA, } \\
\text { MERVAL, OMX, } \\
\text { RTSI RUSSIA, } \\
\text { SENSEX (5) }\end{array}$ & $\begin{array}{l}\text { IBOVESPA, } \\
\text { MERVAL, OMX, } \\
\text { RTSI RUSSIA, } \\
\text { SENSEX (5) }\end{array}$ & $\begin{array}{l}\text { IBOVESPA, } \\
\text { MERVAL, OMX, } \\
\text { RTSI RUSSIA, } \\
\text { SENSEX (5) }\end{array}$ \\
\hline NYSE & $\begin{array}{l}\text { GSPC S\&P500, } \\
\text { IBOVESPA, } \\
\text { MERVAL, } \\
\text { NASDAQ, RTSI } \\
\text { RUSSIA, } \\
\text { SENSEX (6) }\end{array}$ & $\begin{array}{l}\text { GSPC S\&P500, } \\
\text { IBOVESPA, } \\
\text { MERVAL, } \\
\text { NASDAQ, RTSI } \\
\text { RUSSIA, } \\
\text { SENSEX (6) }\end{array}$ & $\begin{array}{l}\text { IBOVESPA, } \\
\text { MERVAL, } \\
\text { NASDAQ, RTSI } \\
\text { RUSSIA, SENSEX } \\
\text { (5) }\end{array}$ & $\begin{array}{l}\text { IBOVESPA, } \\
\text { MERVAL, } \\
\text { NASDAQ, RTSI } \\
\text { RUSSIA, SENSEX } \\
\text { (5) }\end{array}$ \\
\hline OMX & $\begin{array}{ll} & \text { ATX, } \\
\text { RUSSIA, } & \\
\text { SENSEX (3) } & \end{array}$ & $\begin{array}{l}\text { ATX, RTSI } \\
\text { RUSSIA, } \\
\text { SENSEX (3) }\end{array}$ & $\begin{array}{lr}\text { ATX, } & \text { RTSI } \\
\text { RUSSIA, } & \text { SENSEX } \\
\text { (3) } & \end{array}$ & $\begin{array}{lr}\text { ATX, } & \text { RTSI } \\
\text { RUSSIA, } & \text { SENSEX } \\
(\mathbf{3}) & \end{array}$ \\
\hline OSE & DJIA (1) & DJIA (1) & DJIA (1) & DJIA (1) \\
\hline $\begin{array}{l}\text { RTSI } \\
\text { RUSSIA }\end{array}$ & MERVAL (1) & MERVAL (1) & MERVAL (1) & MERVAL (1) \\
\hline \multicolumn{5}{|l|}{ S\& P TSX } \\
\hline \multicolumn{5}{|l|}{ SENSEX } \\
\hline SMI & $\begin{array}{lr}\text { ATX, } & \text { BEL20, } \\
\text { DAX, } & \text { DJIA, } \\
\text { IBEX, } & \\
\text { IBOVESPA, } & \text { IPC, } \\
\text { MERVAL, } \\
\text { NASDAQ, NYSE, } \\
\text { OMX, }\end{array}$ & $\begin{array}{lr}\text { ATX, } & \text { BEL20, } \\
\text { DAX, } & \text { DJIA, } \\
\text { IBEX, } & \\
\text { IBOVESPA, IPC, } \\
\text { MERVAL, } \\
\text { NASDAQ, NYSE, } \\
\text { OMX, OSE, }\end{array}$ & $\begin{array}{lr}\text { ATX, } & \text { BEL20, } \\
\text { DAX, DJIA, IBEX, } \\
\text { IBOVESPA, IPC, } \\
\text { MERVAL, } \\
\text { NASDAQ, NYSE, } \\
\text { OMX, }\end{array}$ & $\begin{array}{lr}\text { ATX, } & \text { BEL20, } \\
\text { DAX, DJIA, IBEX, } \\
\text { IBOVESPA, IPC, } \\
\text { MERVAL, } \\
\text { NASDAQ, NYSE, } \\
\text { OMX, }\end{array}$ \\
\hline
\end{tabular}




\begin{tabular}{|l|l|l|l|l|}
\hline & SENSEX, & SENSEX, & SENSEX, & SENSEX, \\
& STOXX50 (14) & STOXX50 (14) & STOXX50 (14) & STOXX50 (14) \\
\hline \multirow{3}{*}{ STOXX50 RTSI } & ATX, RTSI & ATX, RTSI & ATX, RTSI \\
& RUSSIA, & RUSSIA, & RUSSIA, SENSEX & RUSSIA, SENSEX \\
& SENSEX (3) & SENSEX (3) & $\mathbf{( 3 )}$ & $\mathbf{( 3 )}$ \\
\hline
\end{tabular}

\section{Copyrights}

Copyright for this article is retained by the author(s), with first publication rights granted to the journal. This is an open-access article distributed under the terms and conditions of the Creative Commons Attribution license (http://creativecommons.org/licenses/by/4.0/). 